\title{
Social Identities Formation of Young Urban Middle- Class Women on Instagram in Contemporary Indonesian Society: A Lifestyle Studies
}

\author{
Yasraf Amir Piliang1 \\ Tri Sulistyaningtyas ${ }^{2}$ \\ Yani Suryani ${ }^{3}$ \\ Jejen Jaelani $^{4}$ \\ 1, 2, 3 Faculty of Art and Design, Institut Teknologi Bandung \\ 4 Visual Communication Design, Institut Teknologi Sumatera
}

\begin{abstract}
Instagram is one of the most popular social media in Indonesia, with 62 million monthly active users (kompas.com, 2019). Young urban middle-class women is an interesting phenomenon on Instagram in Indonesia. This research analyses the social identity formation of young urban middle-class women phenomenon on Instagram. The research uses a qualitative method and lifestyle studies theory. The analysis focuses on visual appearance, culture, and the formation of socio-cultural identities of young urban middle-class women on Instagram. In earlier times, Indonesian women tend to be positioned in the domestic space by patriarchal culture. But today, Indonesian women appear in urban public space. Young urban middle-class women activities on Instagram change the women position from domestic life to public life. Location marker on Instagram is a feature to show social and class identities. When young urban middleclass women share their photos and videos which marked by location, they manifest social and class identities. The existence of location feature on Instagram emerges new practices in the community. It becomes a sign that represents a lifestyle and social class status. The location of tourist attractions, hotels, airports, islands, beaches, mountains, malls, theaters, restaurants, etc. represent the lifestyle, identities, and social class status of young urban middle-class women. Existence of young urban middle-class women in public spaces or social spaces shows the emerges of the women position in society.
\end{abstract}

Keywords: young urban middle-class women, Instagram, social identities, life style, Indonesia 